\title{
Erratum to: Subclinical non-autoimmune hypothyroidism in children with steroid resistant nephrotic syndrome
}

\author{
Kanika Kapoor $\cdot$ Abhijeet Saha $\cdot$ N. K. Dubey $\cdot$ \\ Parul Goyal · C. P. Suresh · Vinita Batra • \\ Ashish Dutt Upadhayay
}

Published online: 18 July 2013

(C) Japanese Society of Nephrology 2013

\section{Erratum to: Clin Exp Nephrol \\ DOI 10.1007/s10157-013-0800-1}

The original version of this article unfortunately contained errors.

In the "Methods" section of the main text, under the heading "Participants", the sentences that begin with "Remission" and "No response" should read:

Remission was defined as complete (Up/Uc $<0.2 \mathrm{mg} /$ $\mathrm{mg}$ ) or partial $(\mathrm{Up} / \mathrm{Uc}$ between 0.2 and $2 \mathrm{mg} / \mathrm{mg}$, serum albumin $>2.5 \mathrm{~g} / \mathrm{dL}$, and no edema). No response was the presence of nephrotic range proteinuria (Up/Uc $>2 \mathrm{mg} /$ $\mathrm{mg}$ ), serum albumin $<2.5 \mathrm{~g} / \mathrm{dL}$, or edema.

In Table 2, in the first column, for the line "Spot Up/ Uc", the unit should be "mg/mg".

In Table 3, in the first column, for the line "Total duration of illness (years)", the value of SRNS without

The online version of the original article can be found under doi:10.1007/s10157-013-0800-1.

K. Kapoor · A. Saha $(\bowtie) \cdot$ N. K. Dubey · C. P. Suresh

Department of Pediatrics, Postgraduate Institute of Medical Education and Research associated Dr Ram Manohar Lohia Hospital, Room no 406, PGIMER Building, New Delhi 201010,

India

e-mail: drabhijeetsaha@yahoo.com

P. Goyal

Department of Biochemistry, Postgraduate Institute of Medical

Education and Research associated Dr Ram Manohar Lohia

Hospital, New Delhi, India

\section{Batra}

Department of Pathology, GB Pant Hospital, New Delhi, India

\section{A. D. Upadhayay}

Department of Biostatistics, AIIMS, New Delhi, India subclinical hypothyroidism, and the unit for the line "Cumulative dose of prednisolone" were shown incorrectly. The corrected tables are as follows:

Table 2 Biochemical parameters in children with SRNS and controls

\begin{tabular}{llll}
\hline & $\begin{array}{l}\text { SRNS } \\
(n=20)\end{array}$ & $\begin{array}{l}\text { Controls } \\
(n=20)\end{array}$ & $P$ value \\
\hline $\begin{array}{c}\text { Blood urea } \\
(\mathrm{mg} / \mathrm{dL})\end{array}$ & $22.00(15.0-49.0)$ & $19.50(10.0-31.0)$ & 0.162 \\
$\begin{array}{c}\text { Se creatinine } \\
(\mathrm{mg} / \mathrm{dL})\end{array}$ & $0.612 \pm 0.203$ & $0.575 \pm 0.18$ & 0.547 \\
$\begin{array}{l}\text { Se albumin (g/dL) } \\
\text { Se cholesterol }\end{array}$ & $3.54 \pm 0.95$ & $4.07 \pm 0.35$ & 0.026 \\
$\quad 171.0(83-387)$ & $130.0(91-214)$ & 0.002 \\
$\begin{array}{l}\text { Spot Up/Uc } \\
(\mathrm{mg} / \mathrm{mg})\end{array}$ & $0.18(0.06-2.0)$ & $0.15(0.04-0.26)$ & 0.037 \\
$\begin{array}{l}\text { FT3 (pg/dL) } \\
\text { FT4 (ng/dL) }\end{array}$ & $3.00(0.9-4.9)$ & $3.3(2.4-4.5)$ & 0.695 \\
TSH (mIU/L) & $3.9(0.5-13)$ & $2.05(0.6-3.4)$ & 0.06 \\
\hline
\end{tabular}

Values are expressed in mean $\pm \mathrm{SD}$ or median (range) as appropriate 
Table 3 Disease profile in SRNS children with and without subclinical hypothyroidism

\begin{tabular}{llll}
\hline & $\begin{array}{l}\text { SRNS with subclinical } \\
\text { hypothyroidism }(n=6)\end{array}$ & $\begin{array}{l}\text { SRNS without subclinical } \\
\text { hypothyroidism }(n=14)\end{array}$ \\
\hline Age of onset of NS (years) & $2.50(1.29-4.88)$ & $3.67(1.88-8.25)$ \\
Age of onset of SRNS (years) & $3.75(1.88-10.5)$ & $7.35(2.88-12.00)$ \\
Initial (IR)/late resistance (LR) & $2 / 4$ & $3 / 11$ & 0.300 \\
Duration of onset of SRNS to thyroid status & $1.25(0.33-3.94)$ & $1.82(1.38-1.93)$ & 0.364 \\
$\quad$ evaluation (years) & $3.00(2.71-8.38)$ & $2.75(1.9-4.20)$ \\
Total duration of illness (years) & $145.28 \pm 34.29$ & $186.89 \pm 82.60$ \\
Cumulative dose of prednisolone (mg/kg/year) & $3.75 \pm 0.77$ \\
Se albumin $(\mathrm{g} / \mathrm{dL})^{\mathrm{a}}$ & $3.3 \pm 0.94$ & $178.28 \pm 69.89$ \\
Se cholesterol $(\mathrm{g} / \mathrm{dL})^{\mathrm{a}}$ & $199 \pm 33.14$ & 0.534 \\
\hline
\end{tabular}

Values are expressed in median (range)

${ }^{\text {a }}$ Mean \pm SD 